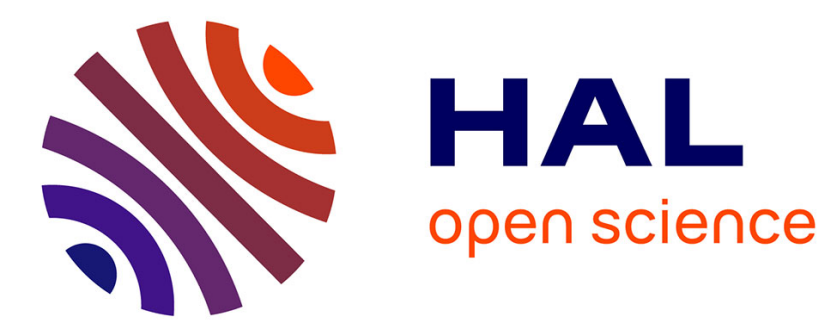

\title{
Economic geography and contemporary rural dynamics: an empirical test on some French regions
}

\author{
Bertrand Schmitt
}

\section{To cite this version:}

Bertrand Schmitt. Economic geography and contemporary rural dynamics: an empirical test on some French regions. Regional Studies, 1999, 33 (8), pp.697-711. 10.1080/00343409950079160 . hal02695637

\section{HAL Id: hal-02695637 \\ https://hal.inrae.fr/hal-02695637}

Submitted on 20 Sep 2021

HAL is a multi-disciplinary open access archive for the deposit and dissemination of scientific research documents, whether they are published or not. The documents may come from teaching and research institutions in France or abroad, or from public or private research centers.
L'archive ouverte pluridisciplinaire HAL, est destinée au dépôt et à la diffusion de documents scientifiques de niveau recherche, publiés ou non, émanant des établissements d'enseignement et de recherche français ou étrangers, des laboratoires publics ou privés. 


\title{
Economic Geography and Contemporary Rural Dynamics: An Empirical Test on Some French Regions
}

\author{
BERTRAND SCHMITT \\ Economie et Sociologie Rurales, Institut National de la Recherche Agronomique (INRA), UMR INRA-ENESAD, \\ 26 bd du Dr Petitjean, BP 1607- F-21036 Dijon Cedex, France
}

This paper presents an economic geography framework used to account for rural population and employment changes. Besides agglomerative forces, these models introduce factors which induce household or fi $\mathrm{rm}$ dispersion that are identifi ed as operative in rural areas. Population dispersion can be the outcome of increased urban land rents. Comparative advantages can affect the location of land-related activities. Technological externalities may lead to the dispersion of specifi $\mathrm{c}$ industrial sectors; and, job increases attract new residents, leading to the dispersion of some $\mathrm{fi}$ rms. We show that all these factors do not act at the same level, and a distinction can be made between forces acting within labour market areas and those acting between labour market areas. A simultaneous equation system is built to model the effect of these forces on population and job changes. It distinguishes different categories of population and jobs. Empirical estimation is based on data from six selected French regions and shows important differences between the forces at work at each level of analysis.

\section{Economic geography Rural areas Population and employment change Simultaneous equation}

Schmitt B. (1999) Economie géographique et dynamique contemporaine des espaces ruraux: un essai de test empirique sur quelques régions françaises, Reg. Studies 33, 697-711. L'article s'appuie sur les travaux récents de l'économie géographique, en vue d'expliquer les dynamiques rurales d'emploi et de population. A côté des forces entraînant l'agglomération des populations et des activités, ces modèles intègrent des facteurs qui, au contraire, induisent la dispersion. Certains sont considérés comme étant à l'œuvre dans les dynamiques rurales contemporaines, l'accroissement des prix fonciers urbains entraînant une dispersion de la population, des avantages comparatifs jouant sur la localisation d'activités liées au sol et des externalités technologiques entraînant la dispersion de certaines industries. En outre, la dispersion des emplois attirent la population dont la dispersion induit une certaine dispersion des firmes distributrices. L'analyse montre que ces facteurs ne jouent pas tous à la même échelle et qu'il y a lieu de distinguer les forces à l'œuvre au sein des bassins d'emplois et celles qui jouent entre bassins d'emploi. Un modèle à équations simultanées reliant évolution de la population et évolution des emplois et distinguant plusieurs catégories de population et d'emploi, est construit et testé sur des données provenant de six régions françaises. Les estimations montrent d'importantes différences dans les forces à l'œuvre à chaque niveau d'analyse.

Economie géographique Espaces ruraux

Dynamique de population et d'emploi

Modèle à équations simultanées
Schmitt B. (1999) Wirtschaftsgeographie und gegenwärtige Dynamik ländlicher Gebiete: eine empirische Prüfung ausgewählter französischer Regionen, Reg. Studies 33, 697711. Dieser Aufsatz legt einen wirtschaftsgeographischen Rahmen vor, der dazu benutzt wird, Veränderungen in der ländlichen Bevölkerung und im Arbeitsmarkt zu erklären. Außer agglomerativen Kräften stellen diese Modelle Faktoren vor, die Haushalts- oder Firmenstreuung bewirken, die als entscheidend für ländliche Gebiete erkannt werden. Bevölkerungsstreuung kann das Ergebnis ansteigender städtischer Grundstückspreise sein. Verhältnismäßige Vorteile können sich auf die Standorte landbezogener Tätigkeiten auswirken. Technologische Außenfaktoren können zur Aufsplitterung spezifischer Industriesektoren führen. Darüberhinaus können Stellenangebote neue Einwohner anlocken, was wiederum zur Zersplitterung von Firmen führt. Es wird gezeigt, das all diese Faktoren nicht auf der gleichen Ebene wirken, und es ist möglich, einen Unterschied zwischen Kräften festzustellen, die in einem Arbeitsmarktgebiet, und jenen, die zwischen Arbeitsmarktgebieten auftreten. Es wird ein Simultangleichungssystem aufgestellt, um die Auswirkung dieser Kräfte aufBevölkerung und Arbeitsplatzwechsel darzustellen. Es unterscheidet zwischen verschiedenen Bevölkerungs- und Beschäftigungskategorien. Empirische Schätzungen stützen sich auf Daten von sechs ausgewählten französischen Regionen, und zeigen bedeutende Unterschiede zwischen den Kräften auf, die auf jeder Ebene der Analyse vorkommen.

Wirtschaftsgeographie Ländliche Gebiete Veränderungen in Bevölkerung und Beschäftigung Simultangleichung 


\section{INTRODUCTION}

Regional scientists have never had a large interest in rural areas. Their work focuses on the regional level or on urban issues (see, for instance, NIJKAMP, 1986). Yet rural areas cover a large percentage of territory in Europe as well as in the US, and almost 20\% of the European population lives in them. Furthermore, recent rural changes show some interesting reversals. For instance, in France one can observe from the 1975, 1982 and 1990 Censuses a rural population increase, particularly around cities but also in much more remote areas. This increase is the result of positive migration balance and a natural balance which is becoming negative (FAnOUillet, 1993). Meanwhile rural employment continues to decrease but the rate of decrease is slowing. Net employment decline arises mainly from a reduction in agricultural jobs which is not made up for in the tertiary jobs' increase. However, industrial employment has decreased at a slower rate in rural than in urban areas (CAVAilhes et al., 1994). These facts are not specific to France. Similar trends are observed in most developed countries (CHAMPION, 1989; Barkley, 1993; Galston and Baehler, 1995).

In order to explain these changes, different causes are explored. Causes of population change can be sought in the determinants of migration (CHAMPION, 1992; Dessendre and Perrier-Cornet, 1996). Employment change may be ascribed to new factors affecting firm location (BEYERS and LINDAHL, 1996; GANNE and BER TRAND, 1996), to the comparative or competitive advantages of rural areas (SARACENO, 1994; SCHMITT, 1996), to some specific characteristics of the rural work force (BLANC and LAGRIFFOUL, 1996; A Ubert, 1997) or to the development of new activities (GIBSON, 1993; GALSTON and BAEHLER, 1995). These analyses have two important characteristics in common. First, they try to move away from rural approaches based on only the agricultural sector. Second, they attempt to get closer to regional science approaches.

Recent work uses more traditional regional science approaches to understanding rural changes. For example, Goffette-NAgot, 1999, shows how the new urban economic framework can be used to analyse population change factors in 'periurban' areas. HUGHes and HOLLAND, 1994, use a core-periphery input-output model to examine what happens in the periphery sectors. BARKLEY et al., 1996, and Goffette-Nagot and Schmitt, 1999, study the rural configuration of population and activities in relation to the urban characteristics. HENRY et al., 1997, analyse the influence of urban growth on population and employment changes in rural hinterland in extending the regional development models of Carlino and Mills, 1987, and BoArnet, 1994.

In this paper we look for the factors of rural population and employment changes in relation to urban agglomeration. Our point of view is that of a core/ periphery structure, and the way in which the population and activity concentration in the core influences the periphery dynamics. To that extent, we can refer to economic geography models such as those developed by KRUGMAN, 1991, which aim at explaining the mechanisms that induce a core/periphery structure. Such models rely on household and firm interactions and, therefore, can shed light on the linkages between population and employment location. Economic geography leads us to emphasize the role of land use competition to explain part of population change. Jobrelated migrations explain another part. The employment change explanations need to look at the comparative advantages of rural areas and at the different kinds of externalities (technological or pecuniary) that may act in these areas.

But the different mechanisms at work in rural areas do not act at the same geographical level. Economic geography models concern mainly two geographical scales: distribution of population and firms within a region or within an urban area, on the one hand; and between regions or between cities, on the other hand. Similarly, we will distinguish two levels. The first one considers the rural area as being the periphery of an urban place and belonging to the same labour market. At this level, we identify factors influencing population and jobs distribution between the urban core and its rural periphery. In this case, the main factor of population and job change is the increase of the land rents in urban places which tends to disperse the population. Employment in population-serving sectors may then follow people. At the second level, we consider labour market areas (LMAs) as a whole (that is, including employment centres and their peripheries), and distinguish two kinds of LMAs: rural versus urban. At this level, our purpose is to understand the forces that drive the population and job distribution into rural LMAs. The forces at work here are those that explain employment changes (comparative advantages for developing new activities, technological or pecuniary externalities). Therefore population is considered to follow jobs. It is only later that jobs can follow people in a circular and cumulative movement.

In order to test our set of hypotheses, a population and employment change model was built which links population and job changes in a simultaneous equation system and assigns them into different categories. The empirical estimation is undertaken at two geographical levels with French data organized following LMAs. As expected, results show some important differences between levels.

In the next section, we present our framework based on the economic geography mechanisms, and suggest some hypotheses about rural population and employment changes. In the third section, the model and data used to estimate it are described, including the presentation of the two levels of analysis. The results of estimation at both levels are examined and discussed 
in section four. Finally, we offer some conclusions and rural policy implications of our results.

\section{CAN THE ECONOMIC GEOGRAPHY FRAMEWORK BE USED TO ANALYSE RURAL CHANGES?}

Before considering how the economic geography framework can be used to study rural change, we will present a brief overview of the mechanisms included in these models. Then we will discuss how dispersive forces may be at work in rural areas. This leads us to suggest hypotheses about rural population and employment changes.

\section{Economic geography and dispersion forces}

The main ideas of KRUGMAN's, 1991, model can be outlined as follows. Consider an economy with two goods: one produced with constant returns to scale (let's say, agriculture) and the other one with increasing returns (industry). Assume, furthermore, that consumers have an incentive to locate where the firms concentrate, because households will derive a higher real wage from the greater variety of the goods that are available there. Suppose, finally, that farmers, because of their need for agricultural land, are spread throughout space. Then, a core/periphery pattern can emerge, that is, all the manufacturing activity may be located in a single place, the rest of the space being devoted to agriculture. This will occur under certain conditions: (1) agglomeration economies are high, that is, internal increasing returns in industry are high, as well as the preference for variety of consumers; (2) the dispersed population (farmers) which have to be served from the city is small; and (3) transport costs of the industrial goods are not too high (otherwise, these transport costs reduce the advantage from agglomeration economies).

More generally, economic geography models seek to establish general spatial equilibrium on the basis of microeconomic mechanisms, usually invoking imperfect competition assumptions. Four main forces of agglomeration are highlighted to explain the formation of spatial equilibrium configurations (FUJITA, 1990; Fujita and Thisse, 1996). Comparative advantage models assume the existence of exogenous spatial heterogeneity which encourages agents who have the same preferences to locate at the same place. Models featuring technological externalities introduce positive non-price interactions between agents which induce them to seek mutual proximity. Monopolistic competition models formalize a cumulative agglomeration process in which firms seek to be close to the most extensive markets, whereas households seek to be close to the places where firms agglomerate so as to benefit from lower prices and a greater variety of goods. Finally, oligopolistic competition models look at the spatial consequences of the strategic location of firms which compete in price and for market areas, thus generating centrifugal and centripetal forces.

Even if these models demonstrate that activity and population tends to concentrate over time, some factors lead to dispersion. First, comparative advantages may act as dispersive forces when the factors of production are fixed (KRUGMAN, 1993) and when the activity that uses them is new and expanding. Also, technological externalities promote concentration of firms but nothing requires that this concentration is necessarily in urban places. Some models introduce competition for land use either within cities (FUJITA and OGAWA, 1982), between cities (ABDEL-RAHMAN and FUJITA, 1993) or in the agricultural sector (FUJITA and KRUGMAN, 1995). The increase of land rents that concentration produces may act as a force that disperses economic agents (firms or/and households). Furthermore, transportation costs play a role in either dispersion or concentration. If they are high and associated with low increasing returns and if a large part of the population is employed in the agricultural sector, then both activity and population tend to disperse following a pattern $a$ la Christaller or Lösch. Conversely, if transportation costs are low and combined with high increasing returns and a small agricultural population, geographical concentration occurs (KRUGMAN, 1991; PUGA, 1998). Commuting costs tend to maintain households close to their jobs, and thus close to firms (Fujita and O GAWA, 1982). The agricultural goods' transport costs act as a counter force to industrial concentration and related population concentration (FUJITA and KRUGMAN, 1995). In the same conditions, congestion can also lead to dispersion (BRAKMAN et al., 1996).

Finally, there are numerous factors which explain dispersion of households and firms. Of course, the mechanisms incorporated into economic geography models and the historical development of their key variables (lower transport costs, greater economies of scale, decreased share of agricultural population) induce a tendency towards the concentration of activities and population in cities. But, under certain conditions, dispersion forces can explain some of the movement of population and employment towards rural areas.

Factors of change in different categories of rural population and jobs

The main tendency in recent urban change is the spread of the active population to urban fringes. In order to explain this, we assume that competition for land use within cities affects households more than firms. According to GoffetTe-NaGOT, 1999, the increase in land prices in cities and the decrease of individual transportation costs promote a rise in the distance between work and home. This is restricted by commuting costs which is the force holding households near firms. This population spread is influenced by the city size because land rents increase with agglomeration. 
Thus, as land rents increase with the city size, so does the dispersion of the active population.

In parallel, a trend towards an urban immigration by retired households has been observed (WARNES and FORD, 1995). Nothing compels them a priori to locate on the periphery of cities because they no longer incur commuting costs. They could spread in line with the attractiveness of rural amenities. But the dispersion of this population remains limited because of the decrease in mobility with age and the necessary proximity to facilities which these households need. Thus the impact of retiree mobility on rural dynamics should be weak.

Finally, working people can move in relation to job change. We must examine if activities exist that can spread towards rural areas and why. In contrast to the general trend towards the concentration of economic activities, some sectors remain scattered or tend to disperse across the area.

Economic geography models usually integrate this phenomenon only through the agricultural sector, but forestry, quarrying and mining could be added. However, we know employment in those sectors is decreasing. By contrast, economic sectors fulfilling recreational demand (leisure and tourism) are expanding in rural areas because of a growing demand for recreation. They produce immovable or low-mobility goods, related to specific attributes of places (amenities) (CAVAIlHes et al., 1994). Thus, these economic activities tend to be spatially distributed according to the fixed 'natural' factors they use, and can involve a relative specialization in some areas. The development of sectors producing low-mobility goods is subject to the effects of transport costs incurred by consumers, therefore it depends on the accessibility of areas having suitable natural resources. According to KRUGMAN, 1993, comparative advantages related to the endowment of fixed factors such as natural resources are not necessarily a factor of agglomeration. They may act as a dispersive factor for activities in line with demand for 'natural goods'.

The case of industrial activities is different. In general they tend to concentrate, but nowadays they decrease faster in urban areas than in rural ones (HILAL et al., 1995). The rural labour force and industrial firms have specific characteristics able to sustain or to develop some industrial activities: small and medium size of firms; low-skilled work force; and comparatively low wage rates (BLANC and LAGRIFFOUL, 1996). We can interpret these as both causes and results of externalities. On the one hand, industrial specialization could offset the low skill levels through the development of specific know-how (BECATTINI, 1990), while an unskilled work force would promote the localization of labourintensive industries. On the other hand, the low wages (for equal skill levels) may be attributed to the existence of a specific mode of labour force management characterized by paternalistic relationships between employers and employees (AUBERT, 1997). The small size of firms allows the existence of such relationships. These mechanisms can work as Marshallian externalities within a production sector. They may explain the location and the development of industries not only in urban centres but also in some low-density areas.

Such economic activities, which do not fit in with the general agglomeration pattern, renew the rural activities. These induce the arrival, by job-related migration, of new population (or at least slow down population departure). This population increase, added to the urban population spread, may work as a counter force to concentration of activities, following economic geography mechanisms. On the one hand, the added transport costs that dispersed consumers incur to purchase manufactured goods and services encourage dispersion of their producers. On the other hand, labour force dispersion (or agglomeration) resulting from the population dispersion (or concentration) encourages all the firms to disperse (or agglomerate). But, in order to separate the two effects referred to above, it would be useful to distinguish between firms producing consumption goods and firms that distribute them. ${ }^{1}$ Except in the cases mentioned above, manufacturing firms tend to follow the general pattern of concentration of activities and they are sensitive to labour market size. By contrast, population-serving firms could be more linked to the population because of the transport costs that households incur to reach them. While transport costs between manufacturing firms and population-serving firms are goods' transport costs, the costs between population-serving firms and households are people transport costs. We assume that the latter are higher overall because: (1) transporting someone costs more than transporting something; and (2) these costs are part of the household budget in which they will be a larger share than in a firm budget. So we have two different sorts of linkages between population and employment changes. First, manufacturing firms seek to locate close to the population because of size and characteristics of the labour market. Second, population-serving firms follow the population change to be closer to the demand and because of the high level of household transport costs.

\section{Two levels of analysis to examine rural changes}

All of the factors at work in rural areas do not act everywhere in the same manner nor with the same intensity. Competition for land use may positively influence population change on the periphery of urban agglomerations while elsewhere demographic change depends more on job-related migrations. On the periphery of urban agglomerations, employment changes are thought to be influenced mainly by the effect of local demand on the population-serving activities. Further away from cities this effect would probably be less marked because of lower population growth, and we can expect to observe the effects of localized comparative advantages related to increasing demand for recreational goods and the effects of rural labour force characteristics. 
Furthermore, the interactions between firms and households may induce population change by the impact of employment opportunities and by the role of the consumers' preference for variety. And they may produce employment change by the impact of local demand on population-serving activities and by the effect of the labour market size on industrial firm location.

We can distinguish between two levels of analysis where the mechanisms of population and employment changes will not be the same. In the first, the rural area is analysed as the hinterland of urban areas where the effects of competition for land use predominate. In the second, the urban core (i.e. employment centre) and its periphery are considered as a whole labour market, and rural labour market areas counter urban ones. In this case, the rural dynamic pattern is dominated by the phenomenon of dispersion of productive activities. The expected linkages which characterize these two levels can be summarized as follows.

Around cities, the dynamics of rural areas may be explained mainly by the increase in land rent due to the competition for land use in the centre. This competition is stronger when concentration increases. The ensuing phenomenon of population deconcentration would affect more particularly the active households keeping an urban job. Population growth in rural areas would be proportionately higher with greater size of the centre, higher job growth in the city and proximity to the centre. In these peripheries where peri-urbanization of active households develops, employment change would mainly concern populationserving jobs. Employment growth rate would be in relation to the amplitude of the local population change. At this level, the other factors of population and activity dispersion would have little or no influence.

The dispersive mechanisms affecting economic activities and the feedback effects they have on population and employment changes act at the labour market area level. We may differentiate between predominantly urban and predominantly rural labour market areas. Comparative advantages and externalities can explain the tendency of some activities to develop in predominantly rural labour market areas. According to our assumptions, endowments of specific natural resources may influence the dynamics of recreational activities provided that the concerned areas are accessible to consumers. The jobs in question here are mainly in the retail sector and personal services. Furthermore, the externalities modifying the characteristics of the labour force and of the industrial firms would be important to the rural industrial jobs in the wide sense (i.e. including services to firms). The 'pecuniary' externalities would be expressed through the effect of population change on industrial employment change via labour market size and through the influence of the variety of goods and personal services on population change. In labour market areas where employment is increasing, the processes of growth amplification can be established by the interplay of the increase in population engaged in such activities and of the increase in activities meeting the demand of this population.

\section{MODEL AND DATA USED}

To test the set of hypotheses presented above, we can build a model of which the core is made up of the linkages between population and employment changes. One question concerns the 'jobs follow people' or 'people follow jobs' problem. To account for this interdependency, population and employment change equations must be written as a two-equation simultaneous system (CARLino and Mills, 1987; BOARnet, 1994; HeNRy et al., 1997):

$$
\begin{aligned}
\Delta P_{o p} & =f(A, \Delta E m p) \\
\Delta E m p & =F(B, \Delta \text { Pop })
\end{aligned}
$$

where: $\Delta$ Pop and $\Delta E m p$ are the total population and employment changes (expressed as growth rates); $A$ and $B$ are the characteristics of the areas which are liable to attract new residents and new businesses. In this model, we assume a joint determination of population and employment changes, since vectors $A$ and $B$ are supposed to be determined outside of the model. Thus, $\Delta$ Pop and $\Delta E m p$ are jointly dependent or endogenous variables; $A$ and $B$ are exogenous variables. The solution to this simultaneous causation problem uses an econometric method named instrumental variables methods (MADDALA, 1992; GREENE, 1997).

Now recall that our assumptions segregate the population into two categories and jobs into at least three: active households and retired households for population; agriculture, manufacturing and populationserving sectors for jobs. The previous model then becomes:

$$
\begin{aligned}
\Delta P_{o p} & =g\left(\Delta \text { Pop }_{A C T}, \Delta \text { Pop }_{R E T}\right) \\
\Delta \text { Pop }_{A C T} & =h\left(\Delta \text { Nat }, K_{H}, \Delta E m p\right) \\
\Delta E m p & =G\left(\Delta E m p_{A G R}, \Delta E m p_{S E R V}, \Delta E m p_{I N D}\right) \\
\Delta E m p_{\text {SERV }} & =H\left(K_{A}, \Delta \text { Pop }\right) \\
\Delta E m p_{I N D} & =I\left(K_{L}, K_{I}, \Delta \text { Pop }\right)
\end{aligned}
$$

where: $\Delta P_{O p_{A C T}}\left(\Delta P_{P p_{R E T}}\right)$ is the active (retired) households' change; $\Delta$ Nat is the natural balance; $\Delta E m p_{A G R}\left(\Delta E m p_{S E R V}\right.$ or $\left.\Delta E m p_{I N D}\right)$ is the change in agricultural (population-serving or industrial) jobs (all changes are expressed as growth rates); $K_{H}$ is a vector of features of the places capable of attracting active households; $K_{A}$ is a vector of rural amenities that may be mobilized for the production of recreational goods; $K_{L}$ is a vector of characteristics of the work force; and $K_{I}$ is a vector of characteristics of the local firms. In this model, the active population change, the populationserving employment change and the manufacturing 
employment change are endogenous variables while the retired population change and the agricultural jobs change are exogenous. This means we assume that employment change has no influence on the retired population change and that the impact of population change on the agricultural jobs change is negligible. But we take into account the role of the agricultural sector in population change (via the total employment change) and that of the retired population in employment change (via the total population change).

As assumed before, the relations between variables in this equation system do not act in the same manner at the two levels of analysis we are focusing on. At the first level (when the rural areas are viewed as periphery of the employment centre), we expect the main following relationships. First, the characteristics of the employment centre and the distance between itself and rural areas should play a main role on the active population change, the job-related migrations (captured by employment change) having only a secondary influence at this level. Second, the employment change should be influenced mainly by the population-serving jobs change and not significantly by industrial employment change. Third, the population-serving employment change should be only due to population change, recreational activities having no influence at this level.

At the second level, rural versus urban areas are considered as labour market areas structured by small versus big employment centres. At this level, we expect to show the role of employment change on the active population change via job-related migrations and the role of population change on industrial jobs as well as on population-serving employment. The meaning of the two latter relationships differs: the first is the sign of labour market size change effect and the second the sign of local demand size change effect. Furthermore, the effect of industrial employment on total employment change should appear and rural amenities should influence the population-serving employment.

In order to distinguish between the two levels of analysis, we need a specific delineation of space. We carried out a delineation into LMAs for six French regions (Alsace, Burgundy, Franche-Comté, Lorraine, Midi-Pyrénées and R hône-Alpes) based on commuting flows between communes. ${ }^{2}$ To that end, we used the MIRABELLE method as elaborated by INSEE (National Institute of Statistics and Economic Studies). In this method, communes are attached to an employment centre in relation to the intensity and the direction of their commuting flows (TERRIER, 1979). This arrangement allows us: (1) to separate the LMAs by the size of their employment centre; and (2) to distinguish within each LMA between different zones of influence by the intensity of the commuting flows to the centre. The first distinction will be used to separate rural and urban LMAs. Goffette-NAGOT and SCHMitT, 1999, showed that the size of the employment centre influences the organization of the LMA. In this paper, the LMAs with a small centre (less than 15,000 inhabitants) will be likened to predominantly rural LMAs and those with medium size or large centres (more than 15,000 inhabitants) to be predominantly urban LMAs. In parallel, the different zones of influence of an employment centre are defined by the intensity of commuting patterns which tie the communes to their LMA. Central zones are composed of communes which are closely linked to their centre. These ties are weaker for the peripheral zones and very weak for independent zones. Table A1 (presented in the Appendix) shows how the six selected regions are divided into LMAs and zones of influence.

Total population $(\triangle P O P)$ and employment $(\Delta E M P)$ changes used at each level of analysis are taken from the 1982 and 1990 French population censuses (25\% sample). They are calculated in growth rates. The natural balance (BILNAT) calculated for each LMA or zone over the period 1982-90 is also expressed as a relative value. The household population was divided into two categories: active households' population, i.e. population of households where the reference person is active but not necessarily occupied (of which change is noted $\triangle M E N A C T$ ) and retired households' population, i.e. where the reference person is retired $(\triangle M E N$ $R E T) .{ }^{3}$ Jobs are divided into three classes: agricultural jobs $(\triangle E M P A G R)$, jobs in retailing and personal services $(\Delta E M P S E R V),{ }^{4}$ other jobs $(\Delta E M P A U T R)$. Even if the latter category is composed of a heterogeneous set of activities, it will be viewed as industrial jobs in the broad sense including, therefore, services to firms and the higher tertiary sector. ${ }^{5}$

The $K_{H}$ vector in equation (4) differs in relation to the level of analysis. At both levels, we used an indicator of variety of locally available goods and personal services. It was constructed by calculating a frequency of residential services $(E Q U I P)^{6}$ for each LMA or zone. We added the previous period (1975-82) population change (VPOP 7582) to see if there is some cumulative phenomenon in population change. At the zone of influence level, the $K_{H}$ vector includes some characteristics of the employment centre and the distance to it. Population at the centre has been selected as the criterion for centre size in the form of the square root (POLPOP). The jobs change in the centre between 1982 and 1990 (VEMPOL) is taken as a measure of the centre dynamic. It is expressed as a relative value. The distance from a zone to its centre (DISTPOL) has been calculated from the mean distance in kilometres between the different communes of the zone and their employment centre, weighted by the commune land area. ${ }^{7}$ This figure corresponds approximately to the mean distance between each point of a zone and its centre.

The difficulty in constructing an indicator of rural amenities is well-known (GOFFETTE-NAGOT, 1999). In order to obtain $K_{A}$ of equation (6), we used the capacity for tourist accommodation (capacity for incoming tourism) of the LMA or zone (CAPTOURI $).{ }^{8}$ This variable provides an approximation of 
the impact of the recreational activities development on the population-serving jobs change.

Work force characteristics, $K_{L}$ in equation (7), have been confined to the skill levels of the local work force (i.e. salaried employees, whether occupied or not, counted at their place of residence). Two indicators were selected. The overall skill level of the work force (QUALIFMO) is based on the ratio of executives and intermediate occupations to manual and clerical workers. The skill level of the blue-collar work force ( QUALIFOUV) is calculated as the ratio of skilled manual workers to unskilled manual workers. The characteristics of the local industrial firms, $K_{I}$ in the same equation, are based indirectly on the initial density (in 1982) of manufacturing jobs (in the narrow sense) included in the models with a quadratic form (DIND 82 and D2IND82) and by the previous period (1975-82) manufacturing jobs' change (VIND7582). The first indicator is the result of the entire industrial history, while the second measures the effect of the recent past only.

Taking into account the variables presented above, we obtain two different empirical models, one for each level of analysis. Assuming linear forms, these models can be written as follows:

For analysis by zone of influence of the employment centres:

$$
\begin{aligned}
\Delta P O P= & \alpha_{1}+\alpha_{2} . \Delta M E N A C T \\
& +\alpha_{3} . \Delta M E N R E T+u_{1}
\end{aligned}
$$

$\triangle M E N A C T=\beta_{1}+\beta_{2} . P O L P O P$

$$
+\beta_{3} . V E M P O L
$$$$
+\beta_{4} . \text { DISTPOL }
$$

$+\beta_{5} . E Q U I P+\beta_{6} . B I L N A T$

$+\beta_{7}$. VPOP7582

$$
+\beta_{8} \cdot \Delta E M P+u_{2}
$$

$\Delta E M P=\delta_{1}+\delta_{2} \cdot \Delta E M P A G R$

$$
+\delta_{3} . \Delta E M P S E R V
$$

$+\delta_{4} \cdot \Delta E M P A U T R+u_{3}$

$$
\begin{aligned}
\Delta E M P S E R V= & \lambda_{1}+\lambda_{2} . \text { CAPTOURI } \\
& +\lambda_{3} \cdot \Delta P O P+u_{4}
\end{aligned}
$$

$$
\begin{aligned}
& \Delta E M P A U T R=v_{1}+v_{2} . D I N D 82+v_{3} . D 2 I N D 82 \\
& +v_{4} \cdot \text { VIND7582+ } v_{5} \text {. QUALIFMO } \\
& +\boldsymbol{v}_{6} \text {. QUALIFOUV } \\
& +v_{7} . \Delta P O P+u_{5}
\end{aligned}
$$

For analysis by labour market area:

$$
\begin{aligned}
& \triangle P O P=\alpha_{4}+\alpha_{5} . \Delta M E N A C T \\
& +\alpha_{6} \cdot \Delta M E N R E T+u_{6} \\
& \triangle M E N A C T=\beta_{9}+\beta_{10} . E Q U I P \\
& +\beta_{11} . B I L N A T \\
& +\beta_{12} . V P O P 7582 \\
& +\beta_{13} \cdot \Delta E M P+u_{7} \\
& \Delta E M P=\delta_{5}+\delta_{6} . \Delta E M P A G R \\
& +\delta_{7} . \Delta E M P S E R V \\
& +\delta_{8} \cdot \Delta E M P A U T R+u_{8} \\
& \Delta E M P S E R V=\lambda_{4}+\lambda_{5} . \text { CAPTOURI } \\
& +\lambda_{6} \cdot \Delta P O P+u_{9} \\
& \triangle E M P A U T R=v_{8}+v_{9} . D I N D 82 \\
& +v_{10} . D 2 I N D 82 \\
& +v_{11} \cdot \text { VIND7582 } \\
& +\boldsymbol{v}_{12} \cdot \mathrm{QUALIFMO} \\
& +v_{13} \cdot \mathrm{QUALIFOUV} \\
& +v_{14} \cdot \Delta P O P+u_{10}
\end{aligned}
$$

where: $u_{1}, u_{2}, u_{3}, u_{4}, u_{5}, u_{6}, u_{7}, u_{8}, u_{9}$, and $u_{10}$ are random disturbance terms that are assumed to be normally and independently distributed with zero mean and constant variance.

To test our set of assumptions at both geographical scales, it was thus decided to calculate two linear models having structures as similar as possible. The zone of influence model only differs from the LMA model by inclusion of the characteristics of the employment centre in the active population change equation. These are simultaneous equation models in which the endogenous variables are:

- the total population change on which retailing and personal service jobs' and other jobs' changes are dependent

- the active households' population change on which the total population change is dependent

- the total employment change on which the active households' population change is dependent

- and the retailing and personal service jobs' and other jobs' changes on which the total employment change is dependent.

Because of simultaneity, these models can not be estimated using the ordinary least squares method (OLS). 
We used three stage least squares (3SLS) with the set of exogenous variables as instrumental variables. Here we have chosen the 3SLS method because it gives more efficient estimators than 2SLS (MADDALA, 1992).

\section{RESULTS FOR SIX SELECTED FRENCH REGIONS}

The results obtained by estimating the systems in equations (8) to (12) and (13) to (17) concern the labour market areas and the zones of influence of six French regions: five in the North-East of the country and one (Midi-Pyrénées) in the South-West. This set of regions provides insight into a large number of contemporary rural situations. However, there is a shortfall of rural areas under the influence of the Paris metropolis and in coastal areas. Furthermore some problems of data reliability can appear when one uses the $25 \%$ sample census at a geographically small scale. In order to reduce them, the analyses were confined to those LMAs with centres greater than 2,000 people. And a minimum size condition for the population of the zones of influence (more than 2,000 inhabitants) was added for the estimation by zone. ${ }^{10}$ For this reason, our results do not include the areas (LMAs or zones) most marked by agricultural activity and therefore the areas where employment and population are declining most steeply.

Estimation results are presented in two steps: first by zones of influence; second by LMAs. Included at each level is the separation between LMAs with a centre greater than 15,000 people and those with a centre smaller than this threshold (from 2,000 to 15,000 people).

\section{Results for the zones of influence level}

Rural areas are first considered as hinterlands of urban centres. The first equation system (equations (8) to (12)), was estimated by introducing as observations the different zones of influence of the 304 employment centres selected. The results are presented in Table 1 . We can summarize them as follows.

Whatever the centre size, the total population change of the zones of influence depends mainly on the active household population change and secondly on retired population change (equation (8)). The parameter of the latter variable is significant but much lower than the former $(0.10$ versus 0.71$)$. The relative weight of each population in the total population can explain this difference.

As could be expected, active household population change is faster when the employment centres are larger and expanding and when the distance from zone to centre is short (equation (9)). These effects are especially marked in zones of influence with medium sized and large centres. ${ }^{11} \mathrm{We}$ can thus attribute them to the sub- urbanization phenomenon and the role of competition for land use in the employment centre. The effects of the preceding variables are supplemented by influences of the natural balance (more marked when the centre is large), of demographic change in the previous period and of total employment change. These last two factors have an equal impact on the active household population change. The first is indicative of the impact of recent demographic past and highlights the existence of the cumulative phenomena. The second measures the effect of job-related migrations. Thus earlier favourable demographic change (which can modify the accommodation conditions of households via the road infrastructure, housing characteristics, etc.) and job creation (which can be induced by population growth) may amplify the urban spread movement.

One of the most interesting results of the first estimation is the lack of effect of non-agricultural productive employment change (i.e. industry in the broad sense) on total employment change in zones influenced by centres greater than 15,000 inhabitants (equation (10)). The parameter of this variable is not significant in this case nor in the general case (all zones). Employment change in these zones is explained mainly by the retailing and personal services jobs change and secondly by the agricultural jobs change. The first is particularly important as a $1 \%$ change in the number is reflected by a $0.51 \%$ change in total employment (for comparison, the same change induces only a $0 \cdot 29 \%$ change in the total jobs in zones influenced by small employment centres). Finally, in those zones, employment change in population-serving sectors is only determined by demographic change with a multiplier coefficient of more than $1 \cdot 3$, while the development of recreational activities does not seem to be a decisive factor (equation (11)).

Thus the event-sequences related to the suburbanization phenomenon seem to characterize the dynamics of zones influenced in centres greater than 15,000 inhabitants. The spread of the active population from the urban centres to their periphery can be attributed to competition for land use. It appears to be more intense when the centre is larger and it decreases with distance. The contribution of the retired population to demographic change is low. And the repercussion of population growth on population-serving jobs is strong. Finally, total employment change is explained by changes in service jobs and not by industrial employment.

Things appear more complex and maybe less relevant to our purpose when the employment centre size falls below the threshold of 15,000 people. One still finds the role of active household population in total population change (equation (8)). The positive effect of centre dynamics and the negative effect of distance to the centre on the active households' spread also appear (equation (9)). The population change influences the retailing and personal service jobs' change (equation (11)), but the contribution of this category of employ- 
Table 1. Estimation results by zone of infl uence

LMAs with centre from

LMAs with centre

2,000 to 15,000 inhabitants

$>15,000$ inhabitants

Total

Number of zones of influence

206

176

382

Equation (8): total population change (1982-90, in \%)

Constant
$\Delta 82 / 90$ active households' population (\%)
$\Delta 82 / 90$ retired households' population (\%)

$\begin{array}{lr}3 \cdot 41 \star \star \star & (7 \cdot 67) \\ 0 \cdot 72^{\star \star \star} & (25.59) \\ 0.075 \star \star \star & (6.78) \\ & 4.31\end{array}$

$\begin{array}{lr}2 \cdot 48 \star \star \star & (5 \cdot 45) \\ 0 \cdot 69 \star \star \star & (38 \cdot 20) \\ 0 \cdot 10 \star \star \star & (9 \cdot 38) \\ & 2 \cdot 84\end{array}$

$3 \cdot 08^{\star \star \star}$

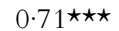

$0 \cdot 095^{\star \star \star}$

$(9 \cdot 56)$

Root of mean square error

Equation (9): active households' population change (1982-90, in \%)
Constant -0.69

Constant

$-0.69$

$(0 \cdot 84)$

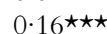

$(3 \cdot 86)$

$\Delta$ employment at centre 82/90 (\%)

$0 \cdot 16^{\star \star \star}$

$(-3 \cdot 21)$

Frequency of residential services

Natural balance 82/90 (\%)

$-1.02 \quad(-0.28)$

$0 \cdot 28^{\star} \quad(1.67)$

$0.44 \star \star \star \quad(5.57)$

$\Delta$ previous population $(75 / 82, \%)$

$\Delta 82 / 90$ employment (\%)

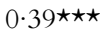

$(7 \cdot 49)$

Root of mean square error

$8 \cdot 14$
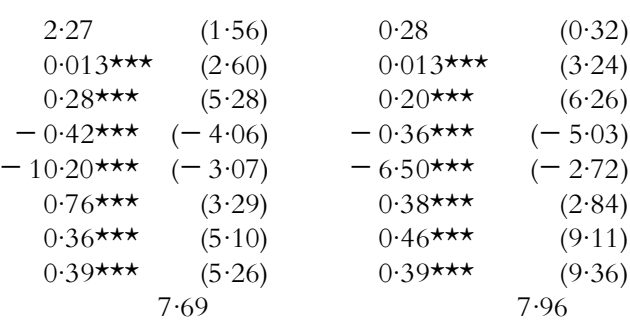

Equation (10): total employment change (1982-90, in \%)
Constant
$-7 \cdot 67 \star \star \star \quad(-4 \cdot 40)$
$0 \cdot 21 \star \star \star \quad(5 \cdot 34)$
$\Delta 82 / 90$ agricultural jobs (\%)

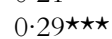
$(5 \cdot 34)$
$(5 \cdot 25)$
$\Delta 82 / 90$ other jobs (\%)
$0 \cdot 46 \star \star \star \quad(6 \cdot 60)$
Root of mean square error
$12 \cdot 0$

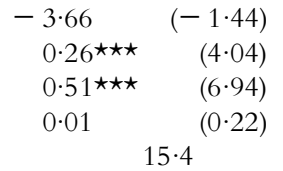

$-7 \cdot 95^{\star \star \star}$

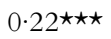

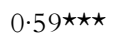

$-0.007$

$15 \cdot 4$

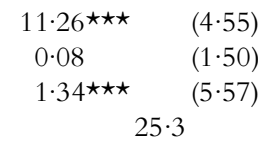

$8 \cdot 65 \star \star \star$
$0 \cdot 17 \star \star \star$
$1 \cdot 47 \star \star \star$

$(4 \cdot 66)$

$(4 \cdot 51)$

(7.19)

$31 \cdot 6$

$-4 \cdot 72)$

$(6 \cdot 56)$

(9.25)

$(-0 \cdot 11)$

$18 \cdot 5$

Equation (11): retailing and personal service jobs' change (1982-90, in \%)

Capacity for incoming tourism

$\Delta 82 / 90$ population $(\%)$
Root of mean square error

$35 \cdot 7$

$(2 \cdot 95)$

$1 \cdot 47 \star \star \star \quad(3 \cdot 90)$

Equation (12): change in non-agricultural jobs other than in retailing and personal services (1982-90, in \%)

Constant
Industrial jobs density in 1982

Industrial jobs density in 1982 squared

$\Delta$ previous industrial jobs $(1975 / 82, \%)$

Work force skill level

Manual work force skill level

$\Delta 82 / 90$ population (\%)

Root of mean square error

$$
\begin{array}{cr}
0.69 & (0.09) \\
-3.32 \star \star \star & (-2.88) \\
0.11^{\star} & (1.87) \\
-0.016 & (-1.18) \\
0.27 & (1.27) \\
-0.013 & (-0.37) \\
1.31 \star \star \star & (4.47) \\
& 24.9
\end{array}
$$

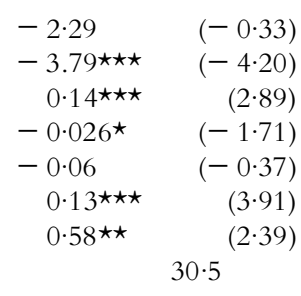

Notes: $\star \star \star$ indicates significance at $0 \cdot 01$; $\star \star$ at $0 \cdot 05$; and $\star$ at $0 \cdot 10$. $\mathrm{T}$-values are in parentheses.

ment to the overall dynamics is clearly weaker and far below the effect that other non-agricultural jobs can have (equation (10)). The change in other jobs is difficult to explain from the results obtained (equation (12)). They may be caused by omitted factors not controlled for.

Finally, the distinction between zones defined by the size of their employment centre yields contrasting results, especially for the role of non-agricultural productive jobs in the dynamics of local employment. It is as if the event sequences linked to sub-urbanization were expressed only above a certain urban centre size.

\section{Results for the Labour Market Areas level}

The purpose of the analysis carried out with the LMAs as observations is to highlight which population and employment change factors differ between LMAs with centres greater than 15,000 inhabitants (i.e. urban LMAs) and those with centres of less than 15,000 inhabitants (i.e. rural LMAs).

None the less both types of LMAs share a number of determinants that are involved with the same intensity, as shown in Table 2. Whatever the centre size, the total population change is influenced more by the active households' population change than by retired households' population change (equation (13)). This fact can be explained by the weight of the two categories in the total population.

Likewise, the natural balance and job-related migrations captured by the role of total employment change are involved similarly in both types of LMAs to explain the active households' population change (equation (14)). The natural balance has a weaker effect than 


\begin{tabular}{|c|c|c|c|c|c|c|}
\hline & $\begin{array}{l}\text { LMAs witl } \\
2,000 \text { to } 15 \text {, }\end{array}$ & $\begin{array}{l}\text { centre from } \\
0 \text { inhabitants }\end{array}$ & $\begin{array}{l}\text { LMAs w } \\
>15,000\end{array}$ & $\begin{array}{l}\text { th centre } \\
\text { inhabitants }\end{array}$ & \multicolumn{2}{|c|}{ Total } \\
\hline Number of LMAs & \multicolumn{2}{|c|}{217} & \multicolumn{2}{|c|}{87} & \multicolumn{2}{|c|}{304} \\
\hline \multicolumn{7}{|c|}{ Equation (13): total population change (1982-90, in \%) } \\
\hline Constant & $2 \cdot 59 \star \star \star$ & $(6 \cdot 55)$ & $2 \cdot 37 \star \star \star$ & $(4 \cdot 54)$ & $2 \cdot 94 \star \star \star$ & $(9 \cdot 29)$ \\
\hline$\Delta 82 / 90$ active households' population (\%) & $0 \cdot 63 \star \star \star$ & $(22 \cdot 64)$ & $0 \cdot 71 \star \star \star$ & $(35 \cdot 51)$ & $0 \cdot 66^{\star \star \star}$ & $(34 \cdot 52)$ \\
\hline$\Delta 82 / 90$ retired households' population (\%) & 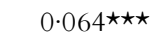 & $(6 \cdot 38)$ & 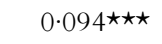 & $(6 \cdot 64)$ & 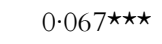 & $(8 \cdot 03)$ \\
\hline Root of mean square error & \multicolumn{2}{|c|}{$2 \cdot 58$} & \multicolumn{2}{|c|}{1.43} & \multicolumn{2}{|c|}{$2 \cdot 38$} \\
\hline \multicolumn{7}{|c|}{ Equation (14): active households' population change (1982-90, in \%) } \\
\hline Constant & $-6.94 \star \star \star$ & $-12 \cdot 01)$ & $-8.63 \star \star \star$ & $(-12 \cdot 07)$ & $-6 \cdot 92^{\star \star \star}$ & $(-15 \cdot 31)$ \\
\hline Frequency of residential services & $0 \cdot 64$ & $(0 \cdot 75)$ & $4 \cdot 39 \star \star \star$ & $(4 \cdot 05)$ & $1 \cdot 21 \star$ & $(1 \cdot 77)$ \\
\hline Natural balance $82 / 90(\%)$ & $0 \cdot 38 \star \star \star$ & $(3 \cdot 68)$ & $0 \cdot 32 \star \star \star$ & $(2 \cdot 81)$ & $0 \cdot 37 \star \star \star$ & $(4 \cdot 70)$ \\
\hline$\Delta$ previous population $(75 / 82, \%)$ & $0 \cdot 19 \star \star$ & $(2 \cdot 46)$ & $0 \cdot 43 \star \star \star$ & $(3 \cdot 65)$ & $0 \cdot 18^{\star \star \star}$ & $(2 \cdot 69)$ \\
\hline$\Delta 82 / 90$ employment $(\%)$ & $0 \cdot 66^{\star \star \star}$ & $(8 \cdot 48)$ & $0 \cdot 63 \star \star \star$ & $(8 \cdot 57)$ & $0 \cdot 71 \star \star \star$ & $(11 \cdot 86)$ \\
\hline Root of mean square error & \multicolumn{2}{|c|}{$5 \cdot 17$} & \multicolumn{2}{|c|}{$3 \cdot 31$} & \multicolumn{2}{|c|}{$4 \cdot 93$} \\
\hline \multicolumn{7}{|c|}{ Equation (15): total employment change (1982-90, in \%) } \\
\hline Constant & $-6 \cdot 68 \star \star \star$ & $(-7 \cdot 38)$ & $-4 \cdot 75^{\star \star \star}$ & $(-5 \cdot 83)$ & $-7 \cdot 00 \star \star \star$ & $(-8 \cdot 42)$ \\
\hline$\Delta 82 / 90$ agricultural jobs (\%) & $0 \cdot 044 \star \star \star$ & $(3 \cdot 09)$ & $0 \cdot 040 \star \star$ & $(2 \cdot 14)$ & $0 \cdot 047 \star \star \star$ & $(4 \cdot 18)$ \\
\hline$\Delta 82 / 90$ retailing and personal service jobs (\%) & $0 \cdot 60 \star \star \star$ & $(10 \cdot 17)$ & $0 \cdot 58 \star \star \star$ & $(11 \cdot 69)$ & $0 \cdot 68 \star \star \star$ & $(12 \cdot 54)$ \\
\hline$\Delta 82 / 90$ other jobs $(\%)$ & $0 \cdot 34 \star \star \star$ & $(7 \cdot 09)$ & $0 \cdot 47 \star \star \star$ & $(13 \cdot 17)$ & $0 \cdot 30 \star \star \star$ & $(8 \cdot 36)$ \\
\hline Root of mean square error & \multicolumn{2}{|c|}{$6 \cdot 76$} & \multicolumn{2}{|c|}{$5 \cdot 85$} & \multicolumn{2}{|c|}{$6 \cdot 84$} \\
\hline \multicolumn{7}{|c|}{ Equation (16): retailing and personal service jobs' change (1982-90, in \%) } \\
\hline Constant & $9 \cdot 81 \star \star \star$ & $(9 \cdot 41)$ & $9 \cdot 69 \star \star \star$ & $(13 \cdot 80)$ & $9 \cdot 52 \star \star \star$ & $(12 \cdot 98)$ \\
\hline Capacity for incoming tourism & $0 \cdot 026^{\star \star}$ & $(1.93)$ & $-0 \cdot 004$ & $(-0 \cdot 33)$ & $0 \cdot 015^{\star}$ & $(1 \cdot 74)$ \\
\hline$\Delta 82 / 90$ population $(\%)$ & $1 \cdot 68^{\star \star \star}$ & $(6 \cdot 93)$ & $1 \cdot 22 \star \star \star$ & $(10 \cdot 46)$ & 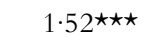 & $(10 \cdot 45)$ \\
\hline Root of mean square error & \multicolumn{2}{|c|}{$13 \cdot 9$} & \multicolumn{2}{|c|}{$5 \cdot 51$} & \multicolumn{2}{|c|}{$12 \cdot 1$} \\
\hline \multicolumn{7}{|c|}{ Equation (17): change in non-agricultural jobs other than in retailing and personal service (1982-90, in \%) } \\
\hline Constant & -0.65 & $(-0 \cdot 11)$ & $6 \cdot 60 \star$ & $(1 \cdot 78)$ & $5 \cdot 53 \star$ & $(1 \cdot 64)$ \\
\hline Industrial jobs density in 1982 & $-0 \cdot 71 \star \star \star$ & $(-3 \cdot 24)$ & $-0 \cdot 82^{\star \star \star}$ & $(-4.99)$ & $-0.83 \star \star \star$ & $(-5 \cdot 73)$ \\
\hline Industrial jobs density in 1982 squared & $0 \cdot 010 \star \star \star$ & $(2 \cdot 66)$ & $0 \cdot 010 \star \star \star$ & $(3 \cdot 15)$ & $0 \cdot 011 \star \star \star$ & $(4 \cdot 11)$ \\
\hline$\Delta$ previous industrial jobs $(1975 / 82, \%)$ & $0 \cdot 050$ & $(1.52)$ & -0.023 & $(-0 \cdot 44)$ & $0 \cdot 051^{\star}$ & $(1.92)$ \\
\hline Work force skill level & $0 \cdot 47 \star \star \star$ & $(2 \cdot 86)$ & $0 \cdot 011$ & $(0 \cdot 13)$ & $0 \cdot 24 \star \star$ & $(2 \cdot 53)$ \\
\hline Manual work force skill level & $-0.092^{\star \star \star}$ & $(-3 \cdot 50)$ & -0.034 & $(-1 \cdot 33)$ & $-0.078 \star \star \star$ & $(-3.94)$ \\
\hline$\Delta 82 / 90$ population $(\%)$ & $0 \cdot 87 \star \star \star$ & $(2 \cdot 81)$ & 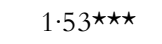 & $(9 \cdot 57)$ & $1 \cdot 08^{\star \star \star}$ & $(5 \cdot 51)$ \\
\hline Root of mean square error & \multicolumn{2}{|c|}{$13 \cdot 9$} & \multicolumn{2}{|c|}{$7 \cdot 63$} & \multicolumn{2}{|c|}{$12 \cdot 2$} \\
\hline
\end{tabular}

Notes: $\star \star \star$ indicates significance at $0 \cdot 01$; $\star \star$ at $0 \cdot 05$; and $\star$ at $0 \cdot 10$. $\mathrm{T}$-values are in parentheses.

employment change. But, in this same equation, two variables differentiate the two types of LMAs. First, the endowment of LMAs in stores and services is positively involved in the active households' population change within urban LMAs, whereas it has no effect in rural LMAs. As expected, we observe in urban LMAs a large effect exercised by the level of supply and the diversity of locally available goods and services. According to the assumptions of economic geography, we can interpret it as the effect of the preference for variety. Second, the past demographic dynamic (viewed by the previous period population change) influences the present demographic pattern more clearly in urban LMAs than in rural ones. The existence of cumulative effects, other than the effect of previous population change on the level of locally available goods and services, may be revealing. One thinks of changes in the conditions of other facilities for households, not only roads and building projects, but also opportunities for social interaction between households.
Viewed at the LMA level, agricultural employment change does little to explain total employment change because of its low impact at this geographical scale (equation (15)). ${ }^{12}$ It is not surprising to find that retailing and personal service jobs are important to total employment change, but it is worth noting that 'other' jobs (i.e. industrial jobs in the broad sense) also contribute significantly to total employment change, whatever the type of LMA.

As expected, the retailing and personal service jobs change depends on the LMA population change (equation (16)). This induction effect appears more substantial in rural LMAs than in the urban ones: a $1 \%$ change in total population entails a $1.68 \%$ change in this category of employment when the employment centre is small versus $1 \cdot 22 \%$ when it is large. The capacity for incoming tourism is an indicator of recreational activities' development. It plays a role in the dynamics of such jobs only in rural LMAs and in this case has a positive effect. Thus, in terms of retailing and personal 
service jobs, rural and urban LMAs differ both in the role of recreational activities and in the size of the employment effects induced by the development of residential services.

The industrial characteristics of the LMA affect the change of other jobs in an ambiguous way (equation (17)). Whatever the type of LMA, the initial density of industrial jobs (in the narrow sense) has a negative effect on other jobs change. However, this effect is reversed for extremely high values of the variable (greater than 70 industrial jobs per $\mathrm{km}^{2}$ ). Conversely, industrial jobs (in the broad sense) move in the same direction as the previous period change of industrial jobs (in the narrow sense, that is, in excluding services to firms). This link is significant when we consider all of the LMAs and the rural LMAs. However the parameter is less significant in the latter case. Thus, as could be assumed a priori, the historically industrial character of an LMA is an unfavourable factor for its contemporary dynamics. But rural LMAs with positive recent industrial change have a non-agricultural productive employment increase.

The skill level of the work force does not explain the change of industrial jobs in the broad sense in the urban LMAs probably because the work force has a more uniform skill level than in rural LMAs. By contrast, it has a significant effect within the rural LMAs. The greater the relative weight of executives and technicians, the more favourable the industrial jobs change, while the greater the skill level of manual labour, the less favourable the change. These two effects can be viewed as contradictory. They can be understood if it is considered that the former affects activities with high human capital content and the latter more traditional industrial activities.

As expected, total population change influences both the retailing and personal service jobs change and the change of industrial jobs in the broad sense. This latter influence appears in both types of LMAs but with a clearly different amplitude. A $1 \%$ change in the population entails a $1.53 \%$ increase in industrial employment in the urban LMAs and only $0.87 \%$ in the rural ones. In view of the assumptions of economic geography, this effect can be attributed to the increased size of labour markets favouring externalities of the matching type, of human capital, of know-how, etc. It is fully active in urban areas but does not exclude the more rural ones even if the impact is less marked.

Thus, the different dynamics of employment within rural LMAs seem to be particularly related to comparative advantage enabling the development of recreational activities, to effects induced by their increased population, to characteristics of their labour force, and to a lesser extent to their industrial past. Employment change is furthermore liable to entail positive demographic change. The urban LMAs differ in the impact of the level of goods and services offered to consumers, in the effect of earlier population growth, and in the role exerted by the labour market increase on the development of (non agricultural) productive activities.

Finally, there are several important differences between the estimation results obtained at each geographical level of analysis. First, at the level of zones of influence, we can stress the lack of role of industrial jobs in rural employment change. This type of employment does not play any role in the case of rural areas under the influence of large or medium sized cities. In these zones the population and employment changes are due to the urban population spread and depend on the centre size and growth. In contrast, the role of industrial jobs becomes strong when the analysis is made at the LMA level whatever the LMA centre size. Second, the industrial jobs equation gives more interesting results at the LMA level than at the zone level. At the LMA level, the characteristics of the work force and the labour market size (via population change) play different roles in the rural and urban LMAs. We observe the same thing for rural amenities (viewed via the capacity for incoming tourism). They seem to act positively only in the case of LMAs with small centres. Third, the job-related migrations (captured via the impact of employment change on population change) have a positive influence on the active population change at each level, but their impact is higher at the LMA level than at the zone level.

Several tests using different sets of variables and instruments were made. ${ }^{13}$ The estimation results did not change very much and the regression results seem robust. In general, the root mean square errors obtained for the two population equations in the different models are lower than the means of related exogenous variables (expressed in absolute values). But it is worth noting that they become generally high for the retailing and personal service jobs' and for the other jobs' equations. First, the capacity for incoming tourism variable is not good enough to explain the development of recreational activities. Furthermore, population change and recreational activities explain just a part of retailing and personal service jobs change. These sectors were affected by a strong concentration which deeply modified their characteristics. This illustrates the complexity of the factors influencing industrial employment change. The main limit of this study is that our set of variables cannot take all of these factors into account. In other words, to improve the explanation of rural industrial change, it would be necessary to increase the reflection of the different externalities at work in the LMA level.

\section{CONCLUSION}

The aim of this paper was to show how economic geography concepts can be used to explain recent rural changes in six French regions. We emphasized the agglomerative and dispersive forces at work in these models to highlight forces at work in rural areas. The 
interplay of competition for land and commuting costs explains part of the urban population spread towards rural areas. The comparative advantages related to rural 'natural' resources can account for the fact that some of the population-serving activities (those related to recreational activities) are dispersing towards more rural areas. This movement supplements that induced by demographic dynamics. In parallel, some specific features of employer-employee relationships are reflected by characteristics of the work force and rural firms, and these have been interpreted as the results of Marshallian externalities. They would not act exclusively in the direction of concentration of activities and could explain the low decrease in rural industrial jobs. The population spread to rural areas comes in as a factor of jobs' dispersion, which is not confined to those firms that distribute consumer goods and services. Industrial activities in the broad sense are also concerned by this effect of labour market size.

We have tried particularly to show that these different mechanisms do not all occur at the same scale of analysis. To understand rural dynamics, two levels of analysis are required based on two views of rural areas. First, these areas may be viewed as hinterlands of urban areas. In this case, their changes are dominated by the classic effects of urban spread, similar to those analysed in suburbanization. Second, they may be viewed as organized territories of which the characteristics are the opposite of those of urban territories. This kind of rural area is more remote and has development less directly related to nearby urban development than in the previous case.

It seems to us that this distinction could be important in a policy perspective. On the outskirts of medium sized and large agglomerations, population change is influenced by the dynamics of local employment but also by employment change within the employment centre. In return it only influences the employment dynamics in retailing and personal services. Industrial activity does not matter for employment change. Thus to stimulate economic activity in these areas, the policies have to emphasize the factors capable of attracting new residents.

In terms of labour market areas, the linkages between population and jobs are more classical: employment change positively influences population change and the latter affects both retailing and personal services jobs and industrial jobs. Here the driving force of economic activities is employment change. Stimulating this employment change in rural labour market areas could be possible in two ways: on the one hand, by emphasizing rural comparative advantage, especially to develop recreational activities in certain places; on the other hand, the relationships between employers and employees and the characteristics of the work force play a role in the industrial change. The policies which are based on these relationships could stimulate economic activity in rural areas. Then population can remain and new residents may be attracted. This population increase enhances the local demand and the labour market size, and both of these stimulate local economic activity.

We have seen that the limits of this study are mainly in its ability to explain the population-serving and industrial job changes. It seems to us to be necessary to examine the factors that underly these changes further. The determinants of productive employment dynamics, whether agricultural or not, have only been given cursory treatment and require much closer theoretical and methodological investigation (for example, in the direction of GLAESER et al., 1992, or HENDERSON et al., 1995). The impact of the accessibility of areas has not been examined in detail, for want of sufficiently precise indicators. The same is true of the influence of rural amenities fostering the development of recreational activities, which has only been possible to include by indirect measurement. The event sequences envisaged remain for the moment in the state of hypotheses.

Acknowledgements - We are grateful to Catherine Baumont, Sylvie Charlot, Florence Goffette-Nagot, Larry Grimes, Mark Henry, Jean-Marie Huriot, Brian Richard, Gabriel Tahar and the two referees for helpful comments and suggestions. This work was made possible by support and assistance from INSEE (Division of Statistics and Regional Surveys: Burgundy region) whom we wish to thank here.

\section{NOTES}

1. This distinction is rarely made in economic geography models. Most of them consider that manufacturing firms deliver their products to households, or that households procure products directly from the firms when commuting to work. Some introduce a population-serving sector (R IVER A-B ATIZ, 1988). But they omit household commuting or shopping costs because they are not investigating the internal organization of cities. The services are then located either at the employment centre or at the household's home. This approach is not a problem as long as households live close to their jobs or as long as shopping trips are combined with commuting. But when commuting increases, we must take into account a possible difference in the location pattern of manufacturing firms and population-serving firms.

2. Communes are French municipalities. They correspond to the lowest level of territorrial division in this country.

3. The remaining households (where the reference person is ranked with 'other inactive') is included in the total population but not individually in the analysis.

4. This category includes employment in retailing (U08 of INSEE nomenclature in NAP 15), merchantable personal services, hotels and catering, automobile repairs and sales (res. T29, T30 \& T33 of NAP 40).

5. Apart from industrial jobs in the narrow sense (U02U06), this set includes such varied sectors as: the building trade, civil and agricultural engineering (U07); transport and communications (U09); services to firms (T34 of NAP 40); rentals and real estate leases (U11); insurance 
(U12); financial institutions (U13); and nonmerchantable services (U14). In this latter, it is difficult to distinguish what comes under production and what under distribution. Some tests aimed at isolating certain items, especially non-merchantable services, proved inconclusive, probably for reasons of data reliability at the geographical levels at which we are working.

6. This frequency is obtained from a selection of 28 (intermediate) stores and services from the 1988 Communal Inventory. For each commune the result depends on the number of facilities and the number of occurrences in the commune. The total frequency obtained by communes in a LMA or zone was converted to a density.

7. Distances between villages and city centre as the crow flies come from the IGN (National Geographic Institute) Lambert co-ordinate file.

8. As given by the 1988 Communal Inventory. The capacity for incoming tourism was converted to a density.

9. At the LMA level, we tried in some preliminary tests to add the accessibility of the LMA. We had chosen the distance to the nearest urban agglomeration greater than 200,000 inhabitants and the distance to the nearest motorway entrance point as given by the 1988 Communal Inventory. These (straight line) distances measured for the commune are converted into a mean value for the LMA and weighted by the land area of the commune. These two indicators did not provide significant results and were not selected in the final estimation.

10. This approach left out $10 \%$ of the regional land areas and only $2.5 \%$ of the population in the analysis by LMAs. These values increased to $20 \%$ of land area and
9\% of population for the analysis by zones of influence (see Table A1 appended).

11. The effect of centre size logically disappears when the analysis is confined to zones influenced by small centres because the variability in centre size dwindles (Table A2 appended).

12. This is in view of the limits of this analysis referred to above and resulting from the elimination of the smallest and most agricultural LMAs.

13. Some tests were mentioned during the data description. We tried also to share the other jobs category in different parts (essentially, between industrial and services jobs or between jobs in merchantable and non-merchantable services). Furthermore variables were deleted either in terms of instrumental variables or in terms of explanatory variables. We also tried to add an equation to make endogenous the retired population change. This showed that the retired population change is only influenced by the natural balance and that its presence in the models does not modify the other results. The results of these tests are available from the author on request. We also tested the exogeneity of our endogenous variables, using the exogenous test with estimation of the augmented regression, based on the specification test of Hausman (MAdDAlA, 1992). This involves the estimation of the different equations, introducing together the estimated value of the tested variable obtained with the regression on the instruments and its observed value. In our different cases (total population change, retailing and personal service jobs' change and other jobs' change variables), the observed variable is significant at the $5 \%$ level, so we accepted the endogeneity assumption.

\section{A P P E NDIX}

Table A1. Breakdown of the six selected French regions by LMA and zone of influence

\begin{tabular}{|c|c|c|c|c|c|c|c|c|}
\hline & \multicolumn{4}{|c|}{ Six regions total } & \multicolumn{4}{|c|}{ Areas included in analysis } \\
\hline & No. & $\begin{array}{c}\text { Surface } \\
(\times 1,000 \\
\left.\mathrm{km}^{2}\right)\end{array}$ & $\begin{array}{c}\text { Population } \\
1990 \\
(\times 1,000)\end{array}$ & $\begin{array}{l}\text { Jobs } 1990 \\
(\times 1,000)\end{array}$ & No. & $\begin{array}{c}\text { Surface } \\
(\times 1,000 \\
\left.\mathrm{km}^{2}\right)\end{array}$ & $\begin{array}{c}\text { Population } \\
1990 \\
(\times 1,000)\end{array}$ & $\begin{array}{l}\text { Jobs } 1990 \\
(\times 1,000)\end{array}$ \\
\hline Labour Market Areas with: & 429 & $179 \cdot 9$ & 14,925 & 5,718 & 304 & $162 \cdot 3$ & 14,559 & 5,582 \\
\hline centre $<2,000$ inhabitants & 125 & $17 \cdot 6$ & 366 & 136 & - & - & - & - \\
\hline centre $2-15,000$ inhabitants & 217 & $60 \cdot 8$ & 2,591 & 945 & 217 & $60 \cdot 8$ & 2,591 & 945 \\
\hline centre $>15,000$ inhabitants & 87 & $101 \cdot 5$ & 11,968 & 4,637 & 87 & $101 \cdot 5$ & 11,968 & 4,637 \\
\hline $\begin{array}{l}\text { Zones of influence (excluding empl } \\
\text { centres): }\end{array}$ & 916 & $157 \cdot 2$ & 5,886 & 1,489 & 382 & $127 \cdot 2$ & 5,411 & 1,367 \\
\hline LMAs centre $<2,000$ inhabitants: & 226 & $14 \cdot 3$ & 219 & 61 & - & - & - & - \\
\hline Central zones & 58 & $1 \cdot 6$ & 32 & 8 & - & - & - & - \\
\hline Peripheral zones & 122 & $9 \cdot 1$ & 145 & 38 & - & - & - & - \\
\hline Independent zones & 46 & $3 \cdot 6$ & 41 & 14 & - & - & - & - \\
\hline LMAs centre $2-15,000$ inhabitants: & 466 & $51 \cdot 7$ & 1,239 & 311 & 206 & $38 \cdot 8$ & 1,021 & 262 \\
\hline Central zones & 188 & $14 \cdot 7$ & 475 & 94 & 74 & $10 \cdot 8$ & 377 & 76 \\
\hline Peripheral zones & 205 & $29 \cdot 6$ & 670 & 180 & 114 & $24 \cdot 3$ & 587 & 161 \\
\hline Independent zones & 73 & $7 \cdot 4$ & 94 & 37 & 18 & $3 \cdot 7$ & 57 & 25 \\
\hline LMAs centre > 15,000 inhabitants: & 224 & $91 \cdot 2$ & 4,428 & 1,117 & 176 & $88 \cdot 4$ & 4,390 & 1,105 \\
\hline Central zones & 85 & $39 \cdot 2$ & 2,624 & 589 & 82 & $39 \cdot 2$ & 2,619 & 588 \\
\hline Peripheral zones & 85 & $44 \cdot 9$ & 1,704 & 494 & 75 & $44 \cdot 2$ & 1,692 & 490 \\
\hline Independent zones & 54 & $7 \cdot 1$ & 100 & 34 & 19 & $5 \cdot 0$ & 79 & 27 \\
\hline
\end{tabular}

Source: 1990 Population Census-Alsace, Burgundy, Franche-Comté, Lorraine, Midi-Pyrénées, Rhône-Alpes. 
Table A2. Mean and standard deviation of variables used for analysis by zone of influence

\begin{tabular}{|c|c|c|c|c|c|c|}
\hline & \multicolumn{2}{|c|}{$\begin{array}{l}\text { Zones of LMAs with } \\
\text { centre from 2,000 to } \\
15,000 \text { inhabitants }\end{array}$} & \multicolumn{2}{|c|}{$\begin{array}{c}\text { Zones of LMAs with } \\
\text { centre }>15,000 \\
\text { inhabitants }\end{array}$} & \multicolumn{2}{|c|}{ Total } \\
\hline & Mean & $\begin{array}{l}\text { Standard } \\
\text { deviation }\end{array}$ & Mean & $\begin{array}{l}\text { Standard } \\
\text { deviation }\end{array}$ & Mean & $\begin{array}{l}\text { Standard } \\
\text { deviation }\end{array}$ \\
\hline Number of zones of influence & \multicolumn{2}{|c|}{206} & \multicolumn{2}{|c|}{176} & \multicolumn{2}{|c|}{382} \\
\hline$\Delta 82 / 90$ total population $(\%)$ & $2 \cdot 35$ & $8 \cdot 06$ & $6 \cdot 31$ & $9 \cdot 58$ & $4 \cdot 17$ & $9 \cdot 00$ \\
\hline$\Delta 82 / 90$ active households' population (\%) & $-4 \cdot 79$ & $12 \cdot 29$ & $0 \cdot 046$ & $13 \cdot 39$ & $-2 \cdot 56$ & $13 \cdot 02$ \\
\hline$\Delta 82 / 90$ total employment (\%) & $-7 \cdot 64$ & $17 \cdot 57$ & $-0 \cdot 66$ & $16 \cdot 14$ & $-4 \cdot 43$ & $17 \cdot 26$ \\
\hline$\Delta 82 / 90$ retailing and personal services employment (\%) & $15 \cdot 21$ & $37 \cdot 82$ & $20 \cdot 39$ & $27 \cdot 45$ & $17 \cdot 60$ & $33 \cdot 50$ \\
\hline$\Delta 82 / 90$ other employment $(\%)$ & $4 \cdot 78$ & $27 \cdot 60$ & $8 \cdot 48$ & $37 \cdot 11$ & $6 \cdot 49$ & $32 \cdot 34$ \\
\hline$\Delta 82 / 90$ retired households' population (\%) & $31 \cdot 83$ & $21 \cdot 92$ & $36 \cdot 91$ & $18 \cdot 97$ & $34 \cdot 17$ & $20 \cdot 74$ \\
\hline Centre population (square root) & $85 \cdot 29$ & $20 \cdot 07$ & $261 \cdot 03$ & $176 \cdot 42$ & $166 \cdot 26$ & $149 \cdot 02$ \\
\hline$\Delta$ Employment at centre $1982-90(\%)$ & $1 \cdot 55$ & $11 \cdot 80$ & $4 \cdot 08$ & $10 \cdot 56$ & $2 \cdot 72$ & $11 \cdot 30$ \\
\hline Distance to centre $(\mathrm{km})$ & $8 \cdot 85$ & $4 \cdot 29$ & $16 \cdot 65$ & $10 \cdot 11$ & $12 \cdot 44$ & $8 \cdot 48$ \\
\hline Frequency of residential services $1988\left(/ \mathrm{km}^{2}\right)$ & $0 \cdot 147$ & $0 \cdot 131$ & $0 \cdot 242$ & $0 \cdot 170$ & $0 \cdot 191$ & $0 \cdot 157$ \\
\hline Natural balance $1982-90(\%)$ & $-1 \cdot 37$ & $3 \cdot 80$ & $0 \cdot 39$ & $3 \cdot 21$ & -0.56 & $3 \cdot 64$ \\
\hline$\Delta 75 / 82$ population $(\%)$ & $2 \cdot 34$ & $8 \cdot 41$ & $7 \cdot 09$ & $10 \cdot 91$ & $4 \cdot 53$ & $9 \cdot 92$ \\
\hline$\Delta$ Agricultural employment 1982-90 (\%) & $-31 \cdot 94$ & $19 \cdot 01$ & $-28 \cdot 64$ & $13 \cdot 12$ & $-30 \cdot 42$ & $16 \cdot 62$ \\
\hline Capacity for incoming tourism 1988 (places $/ \mathrm{km}^{2}$ ) & $22 \cdot 33$ & $34 \cdot 55$ & $21 \cdot 97$ & $30 \cdot 68$ & $22 \cdot 16$ & $32 \cdot 78$ \\
\hline 82 Industrial employment density & $2 \cdot 56$ & $3 \cdot 89$ & $3 \cdot 59$ & $3 \cdot 95$ & $3 \cdot 03$ & $3 \cdot 95$ \\
\hline$\Delta 75 / 82$ Industrial employment (\%) & $15 \cdot 44$ & $113 \cdot 87$ & $2 \cdot 52$ & $43 \cdot 31$ & $9 \cdot 49$ & $88 \cdot 76$ \\
\hline Work force skill level & $32 \cdot 81$ & $9 \cdot 58$ & $38 \cdot 31$ & $10 \cdot 39$ & $35 \cdot 35$ & $10 \cdot 32$ \\
\hline Manual work force skill level & $125 \cdot 72$ & $49 \cdot 36$ & $140 \cdot 02$ & $45 \cdot 13$ & $132 \cdot 30$ & $47 \cdot 93$ \\
\hline
\end{tabular}

Sources: 1975, 1982, 1990 Population Censuses; 1988 Communal Inventory.

Table A3. Mean and standard deviation of variables used for analysis by LMA

\begin{tabular}{|c|c|c|c|c|c|c|}
\hline & \multicolumn{2}{|c|}{$\begin{array}{c}\text { LMAs with centre from } \\
2,000 \text { to } 15,000 \\
\text { inhabitants }\end{array}$} & \multicolumn{2}{|c|}{$\begin{array}{l}\text { LMAs with centre } \\
>15,000 \text { inhabitants }\end{array}$} & \multicolumn{2}{|c|}{ Total } \\
\hline & Mean & $\begin{array}{l}\text { Standard } \\
\text { deviation }\end{array}$ & Mean & $\begin{array}{l}\text { Standard } \\
\text { deviation }\end{array}$ & Mean & $\begin{array}{l}\text { Standard } \\
\text { deviation }\end{array}$ \\
\hline Number of Labour Market Areas & \multicolumn{2}{|c|}{217} & \multicolumn{2}{|c|}{87} & \multicolumn{2}{|c|}{304} \\
\hline$\Delta 82 / 90$ total population $(\%)$ & $-0 \cdot 35$ & $5 \cdot 59$ & $3 \cdot 40$ & $6 \cdot 03$ & 0.72 & $5 \cdot 96$ \\
\hline$\Delta 82 / 90$ active households' population (\%) & $-7 \cdot 98$ & $8 \cdot 45$ & $-3 \cdot 14$ & 8.06 & -6.59 & $8 \cdot 61$ \\
\hline$\Delta 82 / 90$ total employment (\%) & $-2 \cdot 27$ & $10 \cdot 65$ & $1 \cdot 70$ & $9 \cdot 15$ & $-1 \cdot 13$ & $10 \cdot 38$ \\
\hline$\Delta 82 / 90$ retailing and personal services employment (\%) & $9 \cdot 99$ & $15 \cdot 75$ & $13 \cdot 72$ & $8 \cdot 84$ & $11 \cdot 06$ & $14 \cdot 20$ \\
\hline$\Delta 82 / 90$ other employment (\%) & $-0 \cdot 71$ & $16 \cdot 18$ & $-0 \cdot 81$ & $11 \cdot 69$ & $-0 \cdot 74$ & $15 \cdot 01$ \\
\hline$\Delta 82 / 90$ retired households' population (\%) & $31 \cdot 54$ & $14 \cdot 84$ & $34 \cdot 41$ & $9 \cdot 47$ & $32 \cdot 36$ & $13 \cdot 56$ \\
\hline Frequency of residential services $1988\left(/ \mathrm{km}^{2}\right)$ & $0 \cdot 447$ & $0 \cdot 345$ & $0 \cdot 46$ & $0 \cdot 271$ & $0 \cdot 451$ & $0 \cdot 325$ \\
\hline Natural balance $1982-90(\%)$ & $0 \cdot 071$ & $3 \cdot 33$ & $2 \cdot 87$ & $2 \cdot 55$ & $0 \cdot 87$ & $3 \cdot 37$ \\
\hline$\Delta 75 / 82$ population $(\%)$ & $0 \cdot 75$ & $5 \cdot 98$ & $3 \cdot 38$ & $4 \cdot 73$ & $1 \cdot 50$ & $5 \cdot 77$ \\
\hline$\Delta$ Agricultural employment 1982-90 (\%) & $-29 \cdot 89$ & $17 \cdot 34$ & $-28 \cdot 04$ & $9 \cdot 94$ & $-29 \cdot 36$ & $15 \cdot 59$ \\
\hline Capacity for incoming tourism 1988 (places $/ \mathrm{km}^{2}$ ) & $29 \cdot 65$ & $45 \cdot 94$ & $29 \cdot 40$ & $38 \cdot 12$ & $29 \cdot 58$ & $43 \cdot 77$ \\
\hline 82 Industrial employment density & $8 \cdot 28$ & $9 \cdot 09$ & $15 \cdot 04$ & $11 \cdot 87$ & $10 \cdot 21$ & $10 \cdot 41$ \\
\hline$\Delta 75 / 82$ Industrial employment (\%) & $-2 \cdot 24$ & $24 \cdot 75$ & $-7 \cdot 91$ & $13 \cdot 07$ & $-3 \cdot 87$ & $22 \cdot 17$ \\
\hline Work force skill level & $32 \cdot 59$ & $7 \cdot 91$ & $42 \cdot 09$ & $9 \cdot 73$ & $35 \cdot 31$ & $9 \cdot 49$ \\
\hline Manual work force skill level & $114 \cdot 37$ & $37 \cdot 78$ & $129 \cdot 86$ & $28 \cdot 47$ & $118 \cdot 80$ & $36 \cdot 01$ \\
\hline
\end{tabular}

Sources: 1975, 1982, 1990 Population Censuses; 1988 Communal Inventory.

\section{REFERENCES}

Abdel-Rahman H. M. and Fujita M. (1993) Specialization and diversification in a system of cities, J. Urban Econ. 33, $189-222$.

Aubert F. (1997) The workings of the rural labour market: localized approach based on work force management practices, paper for the 48th Seminar of European Association of Agricultural Economics on Rural Restructuring Within Developed Economics, Dijon.

BAR KLey D. L. (Ed) (1993) Economic Adaptation: Alternatives for Nonmetropolitan Areas. Westview, Boulder, CO/San Franscico, CA/Oxford. 
Barkley D. L., Henry M. S. and BAo S. (1996) Identifying 'spread' versus 'backwash' effects in regional economic areas: a density functions approach, Land Econ. 72, 336-57.

Becattini G. (1990) The Marshallian industrial district as a socio-economic notion, in Pyke F., Becattini G. and Sengenberger W. (Eds) Industrial Districts and Inter-firm Co-operation in Italy. International Institute for Labour Studies, Geneva.

Beyers W. B. and Lindahl D. P. (1996) Comparing the competitiveness of rural and urban producer services, paper for the 35th annual meeting of WR SA, Napa, CA.

Blanc M. and LAgRiffoul C. (1996) Mobilité et marchés du travail ruraux: une approche en termes de segmentation, Revue d'Economie Régionale et Urbaine, 96(2), 329-42.

Boarnet M. G. (1994) An empirical model of intrametropolitan population and employment growth, Pap. Reg. Sci. 73, 135-53.

Brakman S., Garretsen H., Gigengack R., Van Marrewijk C. and Wagenvoort R. (1996) Negative feedbacks in the economy and industrial location, J. Reg. Sci. 36(4), 631-51.

Carlino G. A. and Mills E. S. (1987) The determinants of county growth, J. Reg. Sci. 27, 39-54.

Cavailhes J., Dessendre C., Goffette-Nagot F. and Schmitt B. (1994) Change in the French countryside: some analytical propositions, Europ. Rev. Agric. Econ. 21(3/4), 429-49.

Champion A. G. (Ed) (1989) Counterurbanization. Edward Arnold, London.

Champion A. G. (1992) Urban and regional demographic trends in the developed world, Urban Studies 29(3/4), 461-82.

Dessendre C. and Perrier-Cornet P. (1996) Insertion professionnelle des jeunes d'origine rurale: les enjeux des choix de localisation, Revue d'Economie Régionale et Urbaine 96(2), 343-62.

Fanouillet C. (1993) L'influence des villes ne cesse de s'accroître, in INSEE, Données sociales 1993. INSEE, Paris.

Fujita M. (1990) Spatial interactions and agglomeration in urban economics, in Chatterji M. and KunNe R. E. (Eds) New Frontiers in Regional Science. Macmillan, London.

Fujita M. and Krugman P. (1995) When is economy monocentric? Von Thünen and Chamberlin unified, Reg. Sci. Urban Econ. 25, 505-28.

Fujita M. and Ogawa H. (1982) Multiple equilibria and structural transition of non-monocentric urban configurations, Reg. Sci. Urban Econ. 12, 161-96.

Fujita M. and Thisse J. F. (1996) Economics of agglomeration, J. Jap. E Int. Econ. 10, 339-78.

Galston W. and Baehler K. (1995) Rural Development in the United States: Connecting Theory, Practice and Possibilities. Island Press, Washington, DC.

Ganne B. and Bertrand N. (1996) P.M.E. et milieu rural: changer les problématiques, Revue d'Economie Régionale et Urbaine 96(2), 283-306.

Gibson L. J. (1993) The potential for tourism development in nonmetropolitan areas, in BARKLEY D. L. (Ed) Economic Adaptation, Alternatives for Nonmetropolitan Areas. Westview, Boulder, CO/San Francisco, CA/Oxford.

Glaeser E. L., Kallal H. D., Scheinkman J. A. and Sheifer A. (1992) Growth in cities, J. Pol. Econ. 100(6), 1,126-52.

Goffette-Nagot F. (1999) Urban spread beyond the city edge, in Huriot J.-M. and Thisse J.-F. (Eds) Economics of Cities. Cambridge University Press, Cambridge.

Goffette-Nagot F. and Schmitt B. (1999) Agglomeration economies and spatial configurations in rural areas, Environ. Plann. A 31, 1,239-57.

Greene W. H. (1997) Econometric Analysis. Prentice-Hall, Englewood Cliffs, NJ.

Henderson V., Kuncoro A. and Turner M. (1995) Industrial development in cities, J. Pol. Econ. 103(5), 1,067-90.

Henry M. S., BArkley D. L. and Bao S. (1997) The hinterland's stake in metropolitan growth: evidence from selected southern regions, J. Reg. Sci. 37(3), 479-501.

Hilal M., Piguet V. and Schmitt B. (1995) Communes rurales et petites villes dans la hiérarchie urbaine, Economie et Statistique 282, 21-36.

Hughes D. and Holland D. (1994) Core-periphery economic linkage: a measure of spread and possible backwash effects for the Washington economy, Land Econ. 70(3), 364-77.

Krugman P. (1991) Increasing returns and economic geography, J. Pol. Econ. 99(3), 483-99.

Krugman P. (1993) First nature, second nature, and metropolitan location, J. Reg. Sci. 33(2), $129-44$.

Maddala G. S. (1992) Introduction to Econometrics. Macmillan, New York.

Nijkamp P. (Ed) (1986) Handbook of Regional and Urban Economics, vol. 1, Regional Economics. North-Holland, Amsterdam/ New York/Oxford/Tokyo.

PugA D. (1998) Urbanisation patterns: European vs. less developed countries, J. Reg. Sci. 38(2), 231-52.

RiverA-B ATIZ F. L. (1988) Increasing returns, monopolistic competition, and agglomeration economies in consumption and production, Reg. Sci. Urban Econ. 18, 125-53.

SARACENo E. (1994) Recent trends in rural development and their conceptualisation, J. Rural Studies 10(4), 321-30.

Schmitт B. (1996) Avantages comparatifs, dynamique de population et d'emploi des espaces ruraux, Revue d'Economie Régionale et Urbaine 96(2), 363-82.

TER RiER C. (1979) Une méthode d'analyse des relations intercommunales (ou la classification d'un graphe valué), L'Informatique Nouvelle 104, 28-30, 105, 15-23.

Warnes A. M. and Ford R. (1995) Housing aspirations and migration in later life: developments during the 1980s, Pap. Reg. Sci. 74(4), 361-87. 